\title{
PENGARUH CARA PENYAJIAN DAN LAMANYA WAKTU PAJANAN TERHADAP KUALITAS SUSU FORMULA ANAK-ANAK
}

\author{
Ra. Hoetary Tirta Amallia ${ }^{1 *}$, Tri Anggraini \\ ${ }^{1}$ Program Studi Biologi Fakultas Sains dan Teknologi UIN RAden Fatah Palembang \\ *Email :Taryardiansyah@yahoo.co.id
}

\begin{abstract}
Milk is an excellent food for human life, especially in children because the ideal composition. Milk formula is made from cow's milk instead of breast milk. Reason mother do not breast feeding mothers are not enough. Causing high nutritional value of milk is easily destroyed by microorganisms for growth and development so that in a very short time the is not very suitable for consumption.this research aims to determine the effect of manner of presentation and the length of time of exposure to the quality of children's milk formula. Research is a descriftive analytic study using purely experiment method. Research sample of infant formula is $0-6$ months whitout additional sugar by engineering random sampling. Data collection using thr primary data for the study of data analysis using ANOVA test with significant level P.value $<0,05$.the results showed the average number of coliform in group A $\left(>70^{\circ} \mathrm{C}<2\right.$ jam) 6/100ml, B $\left(>70^{\circ} \mathrm{C}>2\right.$ jam $) 12 / 100 \mathrm{ml}, \mathrm{C}\left(<70^{0} \mathrm{C}<2\right.$ jam $)$ $112 / 100 \mathrm{ml}$, dan $\mathrm{D}\left(<70^{\circ} \mathrm{C}>2 \mathrm{jam}\right) 764 / 100 \mathrm{ml}$. Bivariate test result in a group A with group $\mathrm{C}$ had a P.value of 0,04 while the P.value in group B and group A pick value mean of 0,012 is significant or meaningful value because the value of P.value $<0,05$ means between the water temperature and length of time of exposure affect each other.of the results of this study it can be concluded the influence of water temperature and length of time of exposure. Suggested that mothers and attention to how to prepare infant formula with good quality.
\end{abstract}

Keywords: Water Temperature; Length Of Time Exposure

\section{PENDAHULUAN}

Susu adalah bahan pangan yang sangat baik bagi kehidupan manusia terutama pada anak-anak karena komposisinya yang ideal. Selain itu susu juga mengandung semua zat yang dibutuhkan oleh tubuh, semua zat makanan yang terkandung didalam susu dapat dimanfaatkan oleh tubuh. Nilai gizi yang tinggi menyebabkan air susu mudah rusak kerena merupakan media yang disukai oleh mikroorganisme untuk pertumbuhan dan perkembangannya sehingga dalam waktu yang sangat singkat air susu sangat tidak layak untuk dikonsumsi (Sudono dkk,2003).

Merujuk pada hasil penelitian di Departemen Kesehatan Minnesota, AS, satu dari enam orang yang minum susu segar jadi sakit karena infeksi bakteri atau parasit. Bakteri yang biasa terdapat dalam susu adalah Streptococcus lactis, Aerobacteraerogenes, Escherichia coli, Lactobacillus casei dan Lactobacillus acidophilus (Jawetz dan Adelberg's, 2001), selain itu dalam susu juga sering terdapat Micrococcus, Pseudomonas, Staphylococcus dan Bacillus (Volk dan Wheeler, 1993).

Susu formula menjadi pilihan alternatif bagi ibu yang kurang beruntung dengan ASI, namun harus diperhatikan secara teliti bagaimana cara yang benar untuk membuat dan menyajikan susu formula buat bayi sebelum diminum. Selain kebersihan, lamanya waktu pajanan serta suhu air yang digunakan pun harus diperhatikan karena bakteri akan mati pada suhu lebih dari $70^{\circ} \mathrm{C}$. Misalnya bakteri E.Coli. Selama periode tahun 2001- 2010, para peneliti menemukan 530 kasus infeksi yang diakibatkan oleh konsumsi susu segar. Infeksi tersebut diakibatkan salah satunya oleh bakteri Salmonella E coli dan Campylobacter. Susu yang masih di dalam kelenjar susu dapat dikatakan steril, tetapi setelah keluar dari ambing dapat terjadi kontaminasi. Kontaminasi tersebut dapat berasal dari berbagai sumber yaitu dari ambing sapi, tubuh sapi, debu di udara, peralatan yang kotor dan manusia yang melakukan pemerahan. Akibat dari pencemaran tersebut dapat berdampak pada kandungan mikroorganisme khususnya bakteri di dalam susu tersebut. Kandungan bakteri akan meningkat sejalan dengan pertambahan waktu. Kandungan bakteri di dalam susu segar kurang dari 1.000 bakteri tiap milliliter dan selama produksi akan diperoleh lebih dari 1.000 .000 bakteri per milliliter susu. Adanya pertambahan jumlah bakteri 
mengindikasikan bahwa susu tersebut tidak layak dan tidak aman untuk dikonsumsi.

Selain itu, fenomena yang baru ditemukan adalah bateri Sakazaki. Enterobacter sakazakii adalah bakteri opportunistic pathogen yang sampai saat ini belum diketahui secara lengkap tentang ekologi, taksonomi, virulensi maupun karakteristik lainnya. Enterobacter sakazakii pertama kali ditemukan pada 1958 pada 78 kasus bayi dengan infeksi meningitis. Urmenyi and Franklin melaporkan adanya kasus meningitis, septicemia dan enterocolitis necrotic yang disebabkan oleh infeksi Enterobacter sakazakii..)

Ditjenak (1982) melaporkan bahwa E. coli keluar dari tubuh bersama tinja dalam jumlah besar serta mampu bertahan sampai beberapa minggu. Kelangsungan hidup dan replikasi $E$. coli di lingkungan membentuk koliform. E.coli tidak tahan terhadap keadaan kering atau desinfektan biasa. Bakteri ini akan mati pada suhu $60{ }^{\circ} \mathrm{C}$ selama 30 menit. Jumlah bakteri Escherichia coli yang telah ditetapkan sebagai mikroorganisme indikator penentuan mutu susu segar, terutama bila diproduksi. Hasil penelitian Cucu Suherna (2009)menunjukkan bahwa persentase kejadian diare pada anak usia 0-24 bulan yaitu sebesar $52,9 \%$. Secara statistik hasil penelitian ini adalah sebagai berikut: cara pengenceran susu formula, cara penyimpanan sisa susu di dalam botol dan cara penyimpanan susu setelah pengenceran masingmasing tidak mempunyai hubungan yang bermakna dengan kejadian diare pada anak usia 0-24 bulan. Penyakit jangka panjang yang disebabkan oleh infeksi patogen dalam susu segar antara lain Guillain-Barre, atau gangguan sistem saraf, juga radang sendi. Disini penulis beranggapan bahwa salah satu faktor penunjang kontaminasi bakteri pada susu adalah dari cara pembuatannya terutama suhu air yang digunakan karena bakteri akan mati pada suhu diatas $70^{\circ} \mathrm{C}$ serta lamanya waktu pajanan serta ditunjang dengan prilaku ibu yang kurang baik. Dasar asumsi ini menuntun penulis kepada pertanyaan sebagai berikut: Apakah ada pengaruh cara penyajian dan lamanya pajanan terhadap kualitas susu formula anak-anak.

\section{METODE PENELITIAN}

Penelitian ini menggunakan penelitian diskriftif analitik yang bertujuan untuk mengetahui hubungankualitas susu formula dengan proses pembuatan susu dan lamanya waktu pajanan. Dengan variabel bebasnya cara pembuatan dan lamanya waktu pajanan dan variabel terikatnya kualitas susu formula. Untuk mengetahui kualitas susu formula di gunakan uji coliform.

\section{HASIL DAN PEMBAHASAN}

\section{A. Hasil}

Tabel 1. Distribusi frekuensi coliform pada susu formula yang dibuat dengan menggunakan air hangat ( $>70^{\circ} \mathrm{C}$ ) dan lamanya waktu pajanan kurang dari 2 jam.

\begin{tabular}{ccc}
\hline Kode Sampel & Coliform & Kesimpulan \\
\hline A1 & $23 / 100 \mathrm{ml}$ & Positif \\
A2 & $2 / 100 \mathrm{ml}$ & Positif \\
A3 & $5 / 100 \mathrm{ml}$ & Positif \\
A4 & $8 / 100 \mathrm{ml}$ & Positif \\
A5 & $<2 / 100 \mathrm{ml}$ & Positif \\
A6 & $<2 / 100 \mathrm{ml}$ & Positif \\
A7 & $4 / 100 \mathrm{ml}$ & Positif \\
A8 & $5 / 100 \mathrm{ml}$ & Positif \\
Rata-rata & $6 / 100 \mathrm{ml}$ & Positif \\
\hline
\end{tabular}

Berdasarkan tabel di atas, dapat dilihat angka coliform pada susu formula yang di buat dengan air hangat $\left(>70^{\circ} \mathrm{C}\right)$ dan lamanya waktu pajanan kurang dari 2 jam yang dilakukan sebanyak 8 kali pengulangan dengan nilai rata-rata angka coliform 6/100ml. 
Tabel 2. Distribusi frekuensi coliform pada susu formula yang dibuat dengan menggunakan air dingin ( $<70^{\circ} \mathrm{C}$ ) dan lamanya waktu pajanan kurang dari 2

\begin{tabular}{ccc}
\hline Kode Sampel & Coliform & Kesimpulan \\
\hline C1 & $27 / 100 \mathrm{ml}$ & Positif \\
C2 & $140 / 100 \mathrm{ml}$ & Positif \\
C3 & $110 / 100 \mathrm{ml}$ & Positif \\
C4 & $110 / 100 \mathrm{ml}$ & Positif \\
C5 & $140 / 100 \mathrm{ml}$ & Positif \\
C6 & $180 / 100 \mathrm{ml}$ & Positif \\
C7 & $94 / 100 \mathrm{ml}$ & Positif \\
C8 & $94 / 100 \mathrm{ml}$ & Positif \\
Rata-rata & $112 / 100 \mathrm{ml}$ & Positif \\
\hline
\end{tabular}

Berdasarkan tabel di atas, dapat dilihat angka coliform pada susu formula yang di buat dengan air dingin $\left(<70^{\circ} \mathrm{C}\right)$ dan lamanya waktu pajanan kurang dari 2 jam yang dilakukan sebanyak 8 kali pengulangan dengan hasil nilai rata-rata angka coliform sebanyak 112/100ml.

Tabel 3. Distribusi frekuensi coliform pada susu formula yang dibuat dengan menggunakan air hangat $\left(>7^{0} \mathrm{C}\right)$ dan lamanya waktu pajanan lebih dari 2 jam.

\begin{tabular}{ccc}
\hline Kode Sampel & Coliform & Kesimpulan \\
\hline B1 & $23 / 100 \mathrm{ml}$ & Positif \\
B2 & $11 / 100 \mathrm{ml}$ & Positif \\
B3 & $13 / 100 \mathrm{ml}$ & Positif \\
B4 & $9 / 100 \mathrm{ml}$ & Positif \\
B5 & $9 / 100 \mathrm{ml}$ & Positif \\
B6 & $9 / 100 \mathrm{ml}$ & Positif \\
B7 & $8 / 100 \mathrm{ml}$ & Positif \\
B8 & $11 / 100 \mathrm{ml}$ & Positif \\
Rata-rata & $12 / 100 \mathrm{ml}$ & Positif \\
\hline
\end{tabular}

Berdasarkan tabel di atas, dapat dilihat angka coliform pada susu formula yang di buat dengan air hangat $\left(>70^{\circ} \mathrm{C}\right)$ dan lamanya waktu pajanan lebih dari 2 jam yang dilakukan sebanyak 8 kali pengulangan yang memiliki nilai rata-rata angka coliform sebanyak $12 / 100 \mathrm{ml}$.

Berdasarkan tabel diatas dapat diketahui bahwa kelompok A jika dibandingkan dengan kelompok $\mathrm{C}$ maka didapatkan nilai P.Value $<0,05$ yaitu 0,04 ini berarti nilainya signifikan atau bermakna. Pada kelompok B jika dibandingkan dengan kelompok A maka didapatkan nilai P.Value $<0,05$ yaitu 0,012 ini berarti signifikan atau bermakna.

Tabel 4. Distribusi frekuensi coliform pada susu formula yang dibuat dengan menggunakan air dingin( $<$ $70^{0} \mathrm{C}$ ) dan lamanya waktu pajanan lebi dari 2 jam.

\begin{tabular}{ccc}
\hline Kode Sampel & Coliform & Kesimpulan \\
\hline D1 & $1.600 / 100 \mathrm{ml}$ & Positif \\
D2 & $920 / 100 \mathrm{ml}$ & Positif \\
D3 & $350 / 100 \mathrm{ml}$ & Positif \\
D4 & $1.600 / 100 \mathrm{ml}$ & Positif \\
D5 & $220 / 100 \mathrm{ml}$ & Positif \\
D6 & $220 / 100 \mathrm{ml}$ & Positif \\
D7 & $280 / 100 \mathrm{ml}$ & Positif \\
D8 & $920 / 100 \mathrm{ml}$ & Positif \\
Rata-rata & $764 / 100 \mathrm{ml}$ & Positif \\
\hline
\end{tabular}

Berdasarkan tabel di atas, dapat dilihat angka coliform pada susu formula yang di buat dengan air dingin $\left(<70^{\circ} \mathrm{C}\right)$ dan lamanya waktu pajanan lebih dari 2 jam yang dilakukan sebanyak 8 kali pengulangan dengan nilai rata-rata angka coliform sebanyak 764/100ml. 
Tabel 5. Pengaruh Cara Penyajian Dan Lamanya Waktu Pajanan Terhadap Kualitas Susu Formula Anak-Anak

\begin{tabular}{ccc}
\hline Variabel & $\begin{array}{c}\text { Kelompok } \\
\text { Penghubung }\end{array}$ & Nilai P \\
\hline \multirow{2}{*}{ Kelompok A } & Kelompok B & 0,056 \\
& Kelompok C & 0,004 \\
& Kelompok D & 0,392 \\
Kelompok B & Kelompok A & 0,012 \\
& Kelompok C & 0,061 \\
\multirow{3}{*}{ Kelompok C } & Kelompok D & 0,733 \\
& Kelompok A & 0,059 \\
\multirow{2}{*}{ Kelompok D } & Kelompok B & 0,266 \\
& Kelompok D & 0,447 \\
& Kelompok A & 0,197 \\
& Kelompok B & 0,644 \\
& Kelompok C & 0,624 \\
\hline
\end{tabular}

\section{B. Pembahasan}

Dari Hasil Penelitian pada kelompok A dengan kelompok $\mathrm{C}$ ada pengaruh antara suhu air dan lamanya waktu pajanan dengan nilai P.Value $<0,05$ yaitu 0,04 sedangkan pada kelompok B dengan kelompok A didapatkan nilai P.Value $<0,05$ yaitu 0,012 ini berarti nilainya signifikan atau bermakna.

Rekomendasi WHO tentang penyajian susu formula harus diperhatikan untuk mengurangi resiko infeksi yakni cara penyajian yang baik dan benar. Cara penyajian susu formula yang baik dan benar diantaranya adalah menyajikan hanya dalam jumlah sedikit atau secukupnya untuk setiap kali minum untuk mengurangi kuantitas dan waktu susu formula terkontaminasi dengan udara kamar. Meminimalkan "hang time" atau waktu antara kontak susu dengan udara kamar hingga saat pemberian. Waktu yang direkomendasikan adalah tidak lebih dari 4 jam. Semakin lama waktu tersebut meningkatkan resiko pertumbuhan mikroba dalam susu formula tersebut.Tetapi apabila susu tersebut telah diminum sebaiknya bila lewat 2 jam dibuang. Hal lain yang penting adalah memperhatikan dengan baik dan benar cara penyajian susu formula bagi bayi, sesuai instruksi dalam kaleng atau petunjuk umum. Menurut Hertina Kalay (2012) sebanyak 62,5\% memiliki tindakan yang tidak baik dalam pemberian susu formula kepada anaknya.Menurut Prof. Dr.Sam Soeharto menjelaskan susu yang sudah diencerkan sebaiknya tidak dibiarkan hingga 2 jam sehingga memungkinkan bakteri berkembang biak . bakteri pada susu mampu memperbanyak diri setiap 20 menit, maka dianjurkan jangan mengonsumsi susu yang sudah disiapkan lebih dari 2 jam. Susu yang sudah disiapkan lebih dari 2 jam harus dibuang dan ganti dengan yang baru.

Penyakit akibat konsumsi bahan pangan tercemar Escherichia coli, bakteri ini menggunakan makanan sebagai media pertumbuhan mereka dan membuat makanan menjadi beracun karena kehadiran mereka (BPOM RI, 2008). Bakteri ini dapat menyebabkan beberapa penyakit berbahaya dan mematikan pada bayi premature, bayi yang baru lahir dengan daya tahan tubuh yang lemah, dan bayi yang baru lahir hingga berumur beberapa minggu.Penyakit pada bayi yang dikaitkan dengan konsumsi susu bubuk formula bayi diantaranya yaitu meningitis dan necrotizing enterocolitis (NEC). (Gitapratiwi et al,2012).

Selain menimbulkan penyakit tersebut, gejala yang ditimbul apabila kita mengkonsumsi makanan atau minuman yang terkontaminasi bakteri Escherichia coli salah satunya adalah diare berdarah dan pada sebagian kecil kasus, gejala juga ditandai dengan adanya sepsis yang dapat menyebabkan kematian (BPOM RI, 2008).

Terjadinya pencemaran pada susu formula oleh bakteri Escherichia coli karena kontaminasi ekternalm yaitu melalui penanganan yang buruk saat merekonstitusi susu formula dengan air atau kontaminasi internal selama produksinya. ( lawleyet al., 2008)

Merujuk pada hasil penelitian di Departemen Kesehatan Minnesota, AS, satu dari enam orang yang minum susu segar jadi sakit karena infeksi bakteri atau parasit. Selama periode tahun 20012010, para peneliti menemukan 530 kasus infeksi yang diakibatkan oleh konsumsi susu segar.Infeksi tersebut diakibatkan salah satunya oleh bakteri Salmonella Escherichia coli dan Campylobacter.

\section{KESIMPULAN}

1. Hasil rata-rata angka coliform pada kelompok A yaitu susu formula yang dibuat dengan menggunakan air hangat $\left(>70^{\circ} \mathrm{C}\right)$ dan lamanyawaktu pajanan kurang dari 2 jam adalah $6 / 100 \mathrm{ml}$.

2. Hasil rata-rata angka coliform pada kelompok B yaitu susu formula yang dibuat dengan menggunakan air hangat $\left(>70^{\circ} \mathrm{C}\right)$ dan lamanya waktu pajanan lebih dari 2 jam adalah 12/100ml. 
3. Hasil rata-rata angka coliform pada kelompok $\mathrm{C}$ yaitu susu formula yang dibuat dengan menggunakan air dingin $\left(<70^{\circ} \mathrm{C}\right)$ dan lamanya waktu pajanan kurang dari 2 jam adalah $112 / 100 \mathrm{ml}$.

4. Hasil rata-rata angka coliform pada kelompok D yaitu susu formula yang dibuat dengan menggunakan air dingin $\left(<70^{\circ} \mathrm{C}\right)$ dan lamanya waktu pajanan lebih dari 2 jam adalah 764/100ml.

5. Dari hasil uji bivariate pada kelompok A dengan kelompok $\mathrm{C}$ ada pengaruh antara suhu air dan lamanya waktu pajanan dengan nilai $\mathrm{P}<0,05$ yaitu 0,04 sedangkan pada kelompok $\mathrm{B}$ dengan kelompok A didapatkan nilai $\mathrm{P}<0,05$ yaitu 0,012 .

\section{DAFTAR PUSTAKA}

[1] AOAC (Association of Official Analytical Chemist). 1996. Official Methods of Analysis, 16th Ed. Association of Official Analytical Chemist, Washington, DC.

[2] Badan POM RI.Makanan dan Minuman. Media masa internet aksestanggal 11 mei 2013.

[3] Badan POM. 2006.Susu Formula. Media masa internet akses tanggal 12 Juni 2013.

[4] BSN. 1995. Gizi,Vitamin dan mineral pada susu formula.media masa internet,akses tanggal 10 Januari 2013.

[5] Dwidjoseputro, D. 1987. Dasar-Dasar Mikrobiologi. Cetakan ke-9. Djambatan. Malang.

[6] FARMER JJ , ASBURY MA, HICKMAN FW, BRENNER DJ and The Enterobacteriaceae Study group. 1980. A new species of Enterobacteriaceae Isolated From Clinical Specimens. InternationalJournal of Systematic Bacteriology. 30(3):569-584.

[7] Geo Brooks. 2001. Mikrobiologi Kedokteran.FK.Uniar

[8] Gitapratiwi, D., DewantiHariyadi, R. danHidayat. 2012. Genetic relatedness of
Cronobacter spp. (EnterobacterSajazakii) isolated from dried food product in Indonesia. Journal 19(4):1745-1749(2012).

[9] NAZAROWEC-WHITE and FARBER JM. 1997. Incidence, Survival and Growth of Enterobacter sakazakii in Infant Formula.Journal of Food Protection, 60:226 230.

[10] Pelczar,Jr.M.J dan E.C.S.Chan. 1988. Dasardasar Mikrobiologi. Diterjemahkan oleh Hadioetomo,R.S.T.Imass,S.S Tjitrosoepomo dan S.L Angka Penerbit UI Press, Jakarta.

[11] SNI. 2009. Jenisdan Batas Maksimum Cemaran Mikroba Dalam Pangan. Jakarta

[12] Sudono.A; Fina Rosdiana dan Budi Setiawa. 2003. Beternak Sapi Perah Secara Intensif. Agromedia Pustaka. Jakarta.

[13] Sudono,kk. 2009. Pengembangan Anak Usia Dini, Grasindo, Jakarta

[14] Suradi, R, dan H.K.P. 2007. Bahan Bacaan Manajemen Laktasi, Jakarta: Perinasia).

[15] WHO. 1989. Jenis -jenis susu formula. Media masa internet,akses tanggal 23 Mei 2013.

[16] FRIEDHEM.2001. Pengukuran Coliform Fecal Dengan MPN. Media masa internet, akses tanggal 25 Mei 2013.

[17] IPB.2007. Bahwa 5 dari 22 sampelsusu formula mengandungbakteri ES. Bakteri. Penelitian Fakultas Kedokteran HewanInstitut Pertanian Bogor.

[18] KIM SH and PARK JH. 2007. Thermal Resistance and Inactivation of Enterobacter sakazakii Isolates During Rehydration of Powdered Infant Formula. J Microbiol Biotechnol. 17 (2): 364-368.

[19] Lawley, Richard, Laurie Curtis \& Judy Davis. (2008). The Food Safety Hazard Guidebook. RSC Publishing.United Kingdom.

[20] Widjaja.2002. Mengatasi Diare dan Keracunan Pada Balita.Tangerang: Kawan Pustaka 